\title{
Deteksi Helminthiasis pada Kuda di Kelompok Kesenian Jaran Kencak Desa Patoman, Banyuwangi
}

\author{
Helminthiasis Detection on Horses in Jaran Kencak Art Groups Patoman Village, \\ Banyuwangi
}

\author{
Nadya Amanda Chaerunissa ${ }^{1 *}$, Vivi Oktaviana ${ }^{1}$, Agus Sunarso², Aditya Yudhana², \\ Kusnoto $^{2}$ \\ ${ }^{1}$ Pendidikan Profesi Dokter Hewan, \\ ${ }^{2}$ Departemen Parasitologi Veteriner, \\ Fakultas Kedokteran Hewan, Universitas Airlangga, \\ Jalan Mulyorejo Kampus C Universitas Airlangga, Surabaya, Indonesia 60115 \\ *Corresponding author: nadyamandac@gmail.com
}

\begin{abstract}
Abstrak
Penelitian ini bertujuan untuk mengidentifikasi helminthiasis yang menyerang kuda di kelompok kesenian "Jaran Kencak" di Desa Patoman, Banyuwangi. Pemeriksaan helminthiasis dilakukan dengan mengambil sampel feses setelah kuda defekasi dan didapatkan sebanyak 11 sampel feses. Tahapan pemeriksaan menggunakan metode natif sederhana di Laboratorium Instrument FKH Unair Banyuwangi. Hasil yang didapatkan $1(9.09 \%)$ dari 11 sampel positif ditemukan larva saluran cerna pada kuda berjenis sandel berumur 20 tahun. Berdasarkan penelitian dari deteksi heminthiasis kuda adalah sebagai upaya penanganan kasus infeksi parasit cacing baik sesama jenis hewan maupun yang beresiko zoonosis terhadap manusia dalam hal ini terutama pemilik kuda.
\end{abstract}

Kata kunci: Banyuwangi, helminthiasis, kuda, Strongylus spp.

\begin{abstract}
This study aimed to determine helminthiasis on horses in the "Jaran Kencak" art group in the Patoman village, Banyuwangi. The examination was done by taking fecal samples after horse defecation and obtained 11 fecal samples. The examination stage uses a simple negative method in the Instrument Laboratory of FKH Unair Banyuwangi. The results obtained from 1 (9.09\%) of the 11 positive samples found in gastrointestinal larvae on a 20-year-old sandel horse. Based on study from helminthiasis detection of horses as an effort to handle cases of worm parasitic infections of both same animal and zoonotic risk to humans in this case, especially horse owners.
\end{abstract}

Key words: Banyuwangi, helminthiasis, horse, Strongylus spp.

Received: 11 April 2019

Revised: 15 Mei 2019

Accepted: 12 Juli 2019

\section{PENDAHULUAN}

Kuda merupakan salah satu golongan ternak di masyarakat dengan populasi yang tidak cukup tinggi. Keberadaan kuda saat ini berperan sebagai sumber pangan, alat transportasi, olahraga atau rekrasi, pertanian, dan untuk perang (Mansyur dkk., 2014). Kuda lokal di Indonesia berasal dari keturunan kuda Sandel Wood dan kuda batak (Oka, 2014).

Pemanfaatan kuda sebagai hiburan yakni pertunjukan kesenian tradisional salah satunya adalah jaranan kencak yang terdapat di beberapa daerah seperti Pasuruan, Jember, Sumenep, dan Banyuwangi. Kesenian Jaran kencak menampilkan kepiawaian kuda yang telah terlatih menari dari sebelum beranjak dewasa mengikuti irama yang dilantunkan oleh penabuh gamelan. Pemilik kuda melatih kuda serta merawat kuda umumnya berada dibelakang rumah pemilik kuda (Devina dkk., 2013).

Kuda merupakan ternak herbivora dengan sistem cerna yang tidak seefektif ruminansia, karena kuda melakukan fermentasi dengan 
mikroba di usus besar. Defekasi kuda mengeluarkan feses padat 10-15 kali dalam sehari dan tidak mudah terserap oleh alas tidur kuda. Perkandangan kuda dilakukan secara tunggal maupun berkelompok. Sanitasi dalam mengendalikan penyakit pada pemeliharaan kuda merupakan hal yang penting. Sanitasi yang buruk sangat beresiko menurunkan kualitas lingkungan dan memicu penyakit infeksi endoparasit cacing (Antaressa, 2011).

Infeksi endoparasit cacing atau helminthiasis dari hewan ternak memiliki angka kematian yang rendah, namun memiliki efek langsung pada produktivitas peternakan dan dampak zoonosis helminthiasis terhadap kesehatan masyarakat yang besar. (Dharmawan, 2015). Kejadian helminthiasis pada kuda di Indonesia sering terjadi dipengaruhi oleh temperatur, iklim, dan sinar matahari. Penelitian oleh (Hafidhi, 2016) mendapatkan beberapa cacing yang menginfeksi saluran pencernaan kuda tunggang wilayah jawa tengah yaitu $73.3 \%$ positif terinfeksi Strongylus $s p$. Penelitian oleh (Widyastuti dkk., 2017) ditemukan prevalensi nematoda yang menginfeksi kuda lokal di Kabupaten Sumbawa sebesar $87 \%$ tipe Strongylus seperti Oxyuris equi $34 \%$ dan Parascaris equorum 4\%. Prevalensi helminthiasis pada kuda penarik di Lombok timur ditemukan endoparasit cacing antara lain Strongylus spp 76\%, Cyathostomes spp 56\%, Triodontopharus spp 32\%, Strongyloides westeri $12 \%$, Oxyuris equi $6 \%$ dan Parascaris equorum 2\% (Oka, 2015).

Diagnosa infeksi parasit cacing pada ternak dapat dilakukan melalui pemeriksaan feses untuk mengidentifikasi jenis dan derajat infeksi parasit cacing serta penggunaan antelmintika yang tepat dan efektif (Andrianty, 2015). Kesehatan pada hewan ternak perlu diperhatikan, karena berkaitan dengan tujuan pemeliharaan serta aspek resiko penularan penyakit dari hewan ke manusia atau bersifat zoonosis (Triakoso, 2009). Tujuan dari pemeriksaan feses untuk deteksi helminthiasis sebagai upaya penanganan kasus zoonosis dari helminthiasis, untuk kemudian dapat dikendalikan dengan memutus siklus hidup parasit (Dharmawan, 2015).

\section{METODE PENELITIAN}

Penelitian menggunakan pendekatan deskriptif yang dilaksanakan pada bulan September 2018. Sampel feses diperoleh dari wilayah Desa Patoman, Kabupaten Banyuwangi. Sampel feses diambil pada tanggal 8 september 2018 dari kuda yang dipergunakan pada pertunjukan jaran kencak di Banyuwangi yang terdiri dari beberapa jenis kuda antara lain, Kuda Sadel, Kuda Jawa, dan Kuda Persilangan Sandel.

Sampel feses yang diapatkan kemudian diletakkan ke dalam pot sampel yang berisikan larutan Alkohol 70\% dan diberi label, dan didapatkan sebanyak 11 sampel yang selanjutnya dilakukan pemeriksaan deteksi cacing menggunakan metode natif sederhana di laboratorium Universitas Airlangga, PSDKU Banyuwangi. Pemeriksaan feses dilakukan dengan mengambil sedikit feses menggunakan ujung batang pengaduk dioleskan diatas gelas obyek dan ditambahkan satu hingga dua tetes air kemudian diratakan serta menutupnya dengan cover glass, selanjutnya dilakukan pemeriksaan dibawah mikroskop dengan pembesaran 100 kali (Mumpuni dkk., 2007).

\section{HASIL DAN PEMBAHASAN}

Hasil pemeriksaan feses kuda menunjukkan bahwa satu diantara 11 ekor kuda terinfeksi parasit cacing pada saluran pencernaan (Tabel $1)$.

Berdasarkan pengamatan pemeriksaan feses tidak ditemukan adanya telur cacing, tetapi ditemukan positif larva cacing pada satu kuda berjenis sandel (Gambar 1). Sampel positif pada kuda kesenian jaran kencak di Desa Patoman, memiliki tingkat prevalensi infeksi helminthiasis yang rendah, sesuai dengan pendapat Oka (2014), pada penelitiannya bahwa kuda yang dengan umur lebih dari 4 tahun memiliki prevalensi infeksinya yang rendah karena imun yang lebih baik. Hasil pemeriksaan feses dilakukan menggunakan mikroskop dan didentifikasi secara morfologi merupakan cacing dari filum nematode, sesuai dengan pendapat 
Tabel 1. Hasil pemeriksaan telur cacing dari sampel feses kuda

\begin{tabular}{ccccc}
\hline No. & Nama Kuda & Umur & Jenis & Hasil Pemeriksaan \\
\hline 1 & Senor & 28 tahun & Sandel & Negatif \\
2 & Kluning & 5 tahun & Sandel & Negatif \\
3 & Suliana & 20 tahun & Sandel & Positif \\
4 & Bojes & 17 tahun & Sandel & Negatif \\
5 & Lintang & 7 tahun & Sandel & Negatif \\
6 & Cahyo & 7 tahun & Sandel & Negatif \\
7 & Trojos & 6 tahun & Sandel & Negatif \\
8 & Dawok & 26 tahun & Sandel & Negatif \\
9 & Alex & 25 tahun & Sandel & Negatif \\
10 & Abimanyu & 18 tahun & Sandel & Negatif \\
11 & Manja & 1,8 tahun & Sandel & Negatif \\
\hline
\end{tabular}

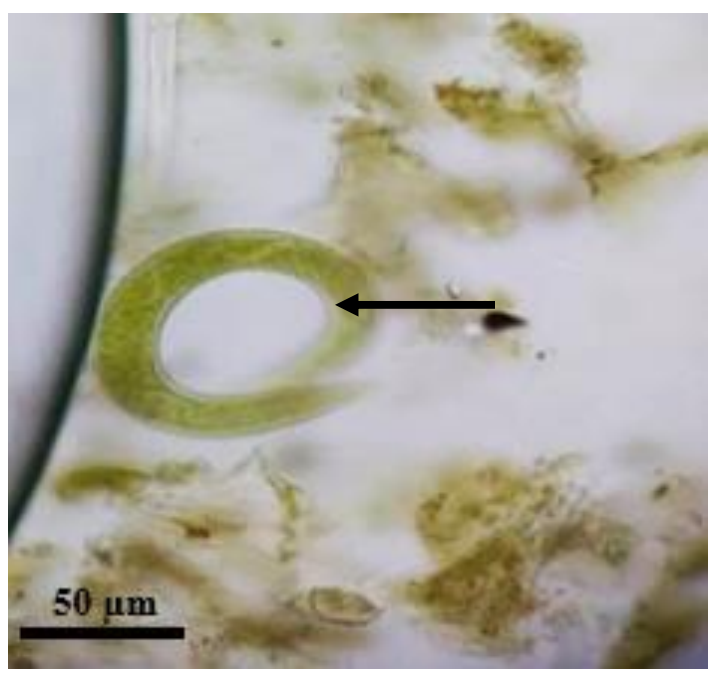

Gambar 1. Larva cacing Nematoda pada feses kuda perbesaran 100 kali

Afifah (2013), bahwa nematoda berbentuk cacing, transparan, tubuh dilapisi oleh kutikula dengan ekor yang runcing.

Beberapa Nematoda yang berada pada saluran pencernaan kuda yaitu, Strongylus vulgaris, Strongylus equines, Strongylus edentatus, Parascaris equorum, Strongyloides westeri, dan Oxyuris equi. (Subekti dkk., 2002). Siklus hidup nematoda secara umum dimulai dari telur yang berkembang selama 7-14 hari dari telur berkembang menjadi larva fase satu, fase dua, hingga fase tiga yang merupakan larva infektif yang erkembang di lingkungan dengan suhu hangat. Larva yang menginfeksi tubuh ternak dapat melalui ingesti rumput yang membawa larva infektif, larva dapat menginfeksi dengan menembus kulit ternak atau dapat melalui daerah kontaminasi oleh feses yang mengandung telur cacing. Larva yang masuk melalui ingesti bergerak mengarah ke jantung dan pulmo menuju saluran pencernaan hingga menjadi cacing dewasa.

Telur cacing dari endoparasit nematoda, ordo Strongylida dengan genus Strongylus spp. Telur genus Strongylus membutuhkan waktu 3 hari untuk menjadi larva infektif dan menginfeksi kuda melalui penetrasi kulit dari larva yang hidup pada rumput di pengembalaan. (Widyastuti dkk., 2017). Berdasarkan (Subekti dkk., 2002) pada cacing dewas Ordo Strongylida memiliki 6 atau 3 bibir atau tanpa bibir, memiliki leaf crown (mahkota duri) dengan siklus reproduksi cacing betina maupun jantan yang berkembang secara sempurna. Cacing betina memiliki uterus dan cacing jantan memiliki bursa dan rays (jari-jari). Ordo Strongylida, memiliki superfamilia dari Strongyloidea, famili Strongyloidae, dan genus strongylus. Pada kuda 
endoparasit nematode dari genus strongylus $s p$ dengan spesies strongylus vulgaris merupakan cacing yang paling beresiko pathogen (Kaplan, 2002).

Parasit cacing terutama tipe strongil, biasanya menginfeksi usus besar kuda dan dapat menyebabkan penyakit mulai dari yang ringan sampai kematian mendadak. Kuda terinfeksi karena memakan rumput yang tercemar telur, larva infektif, atau penetrasi melalui kulit oleh larva infektif. Dampak dari infeksi cacing nematoda gastro intestinal sangat besar yaitu produktivitas kerja yang menurun karena dapat menyebabkan kelemahan, kehilangan berat badan, kolik, nafsu makan hilang, diare bahkan kematian (Hillyer, 2004).

Manifestasi klinis lain berupa anemia, aneurysma, reaksi keradangan, hingga kerusakan pankreas. Perjalanan penyakit pada kasus helminthiasis kuda oleh genus Strongylus ditentukan oleh fase siklus cacing. Larva dan cacing dewasa merupakan fase pathogen. Larva Strongylus vulgaris merupakan yang paling pathogen, larva beredar di aliran darah dan melekat pada dinding pembuluh darah berakibat menimbulkan gumpalan dan aneurysma pada pembuluh darah. Larva Strongylus edentatus mampu bermigrasi kebawah parietal peritoneum hingga menyebabkan peradangan pada peritoneum, Larva Strongylus equines dapat menyebabkan kerusakan pada pankreas. Anemia dan keradangan lain juga dapat disebabkan oleh cacing dewasa yang mengkaitkan diri menggunakan bukal kapsul cacing dewasa ke dinding usus dan menghisap darah penderita menimbulkan hyperemia disertai pembengkakan membrane (Studzińska et al., 2012).

Adapun data mengenai resiko penularan parasit kepada manusia yang menunjukan insidensi terjadinya zoonosis pada helminthiasis berasal dari companion animal yang cenderung tinggi. Riwayat bahwa manusia terpapar parasit cacing dipengaruhi oleh beberapa faktor yang menimbulkan resiko zoonosis infeksi parasit berupa perubahan sosial, diet atau budaya, serta perubahan lingkungan (McCarthy et al., 2000).

\section{KESIMPULAN}

Pemeriksaan 11 sampel feses pada kuda kesenian jaran kencak di Desa Patoman, Banyuwangi didapatkan 1 (9.09\%) kuda yang teridentifikasi positif menderita helminthiasis dari Strongylus spp.

\section{UCAPAN TERIMA KASIH}

Peneliti mengucapkan terima kasih kepada Desa Patoman, Kabupaten Banyuwangi atas izin dan fasilitas yang telah diberikan selama penelitian.

\section{DAFTAR PUSTAKA}

Afifah, L., Rahardjo, B.T., Tarno, H. 2013. Eksplorasi Nematoda Entomopatogen pada Lahan Tanaman Jagung, Kedelai dan Kubis di Malang serta Virulensinya terhadap Spodoptera litura Fabricius. J. Hama dan Penyakit Tumbuhan, 1(2), 1.

Andrianty, V. 2015. Kejadian Nematodiasis Gastrointestinal pada Pedet Sapi Bali di Kec. Marioriwawo, Kab. Soppeng (Doctoral dissertation).

Antaressa, A. 2011. Management of Horse Feces (Equus Caballus) At Nusantara Polo Club (NPC), Karanggan, Bogor.

Devina, S., Bangsa, G., Yudani, H.D. 2013. Perancangan Esai Fotografi Sebagai Penunjang Pelestarian Jaran Kencak Lumajang. J. DKV Adiwarna, 1(2), 10.

Dharmawan, N.S. 2015. Urgensi Penanganan Kasus Helminthiasis Pada Ternak di Wilayah Semi-Ringkai Kepulauan NTT: dengan Referensi Khusus SistiserkosisTaeniasis. Denpasar. Seminar Nasional Ke-3 FKH Undana.

Hafidhi, M.I. 2016. Rekomendasi Anthelmetika Berdasarkan Deteksi Helmintiasis Pada Kuda Tunggang Di Tempat Wisata Kopeng, 
Semarang, Jawa Tengah (Doctoral Dissertation, Universitas Gadjah Mada).

Hillyer, M. 2004. A Practical Approach to Diarrhoea in The Adult Horse. in Practice, 26(1).

Kaplan, R.M. 2002. Anthelmintic resistance in nematodes of horses. Vet. Res., 33(5), 491507.

Mansyur, U.H., Rusmana, D. 2014. Eksplorasi Hijauan Pakan Kuda dan Kandungan Nutrisinya. JITV, 19(3).

McCarthy, J., Moore, T.A. 2000. Emerging helminth zoonoses. Int. J. Parasitol., 30(1213), 1351-1359.

Mumpuni, S., Subekti, S., Koesdarto, S., Puspitawati, H., Kusnoto. 2007. Penuntun Praktikum Ilmu Penyakit Helminth Veteriner. Fakultas Kedokteran Hewan Universitas Airlangga. Surabaya.

Nezar, M.R. 2014. Jenis Cacing pada Feses Sapi di TPA Jatibarang dan KTT Sidomulyo Desa Nongkosawit Semarang (Doctoral Dissertation, Universitas Negeri Semarang).
Oka, D.I.B.M. 2014. Identifikasi Jenis Cacing Nematoda Pada Saluran Gastrointestinal Kuda Penarik Cidomo di Kecamatan Selong, Lombok Timur. Indonesia Medicus Veterinus, 3.

Studzińska, M.B., Tomczuk, K., Demkowska, M., Szczepaniak, K.A. 2012. The Strongylidae Belonging to Strongylus Genus in Horses From Southeastern Poland. Parasitol. Res., 111(4), 1417-1421.

Subekti, S. Koesdarto, S., Sri, M., Halimah, P., Kusnoto. 2002. Diktat kuliah Helmintologi Veteriner. Departemen pendidikan Nasional. Fakultas Kedokteran Hewan. Universitas Airlangga Surabaya.

Widyastuti, S.K., Satria, Y.P., Ida, A.P.A. 2017. Identifikasi dan Prevalensi Nematoda Saluran Pencernaan Kuda Lokal (Equss caballus) di Kecamatan Moyo Hilir Sumbawa. Denpasar. Indonesia Medicus Veterinus.

Triakoso, N. 2009. Aspek Klinik dan Penularan pada Pengendalian Penyakit Ternak. Departemen Klinik Veteriner PKH Universitas Airlangga. 